\title{
River conservation in venezuela: a review
}

Volume 5 Issue I - 2017

\section{Opinion}

The developing nature of Latin America combined with the vastness of its aquatic resources, highly diverse aquatic fauna and flora, rapidly increasing human population, and associated environmental problems, make it a highly priority for international riverine conservation efforts. This citation came from the introduction of a paper published on River conservation in Latin America. ${ }^{1}$

It is only 20 years ago when international scientific community, turns his sight and meet in Santa Cruz, Bolivia 1995 to discuss and establish priorities in aquatic ecosystems conservation in our continent. ${ }^{2,3}$ Since then, several countries, including Venezuela, developed several strategies to increase the knowledge on: inventory (types), dynamics, interrelationships, connections, flora, fauna, and other natural resources important to human life, identifying and classifying several "hot spots" based in biodiversity and endemism. The Aqua Rap program (2000-2010), as one example, studied important areas throughout South and Central America including the Rio Orthon (Bolivia) Upper Rio Paraguay (Paraguay), Southern Pantanal (Brazil), Rio Pastaza (Ecuador and Peru), Copename River (Suriname), Laguna del Tigre National Park, Peten (Guatemala), and the Caura, Paragua, Cuyuni rivers, and the Orinoco River Delta in Venezuela; serving as a vehicle for uncovering the wealth of aquatic biodiversity, for learning that watersheds are tightly structured, for developed standards, method and protocols to be used in study of watersheds, training professionals and students, for stimulating worldwide conservation activities on freshwaters, for direct conservation action programs, and scientific publications. ${ }^{4}$

Taking in account several research results we could conclude that comparison of recent regional conservation assessments of freshwaters, ${ }^{3,4}$ and terrestrial such as Dinerstein et al. ${ }^{2}$ biodiversity in our countries, indicate that freshwater habitats are more seriously threatened taking in account spatial and the severity of the threats.

As far as 1994, I published a list of threats to aquatic habitats in Venezuela. ${ }^{5}$ In it I summarized and discussed geographically the major factors that intervene in losses, and diminishing water quality threaten wild life, and human populations such as: deforestation in the Andes slopes, agriculture and pesticides in low land savannas, domestic, and industrial contaminated effluents along important rivers on the north and western areas in the Orinoco River Basin. Since then, two major threats are developing. 1) Exploration and exploitation of the Orinoco Bituminous Belt covering an extended area along the northern region of the Orinoco River from the Apure-Barinas states to Delta Amacuro in the Atlantic coast and 2) the so-called Orinoco Mining Arch (Arco Minero del Orinoco) along the south region of the Orinoco in an extended area of $112.000 \mathrm{Km} 2$. Both government developing projects are, and will affect, major river basins until now pristine (i.e "morichales" palm-tree communities), and site of the most diverse flora and wildlife fauna in the Guiana Shield. But also, heavy metal contaminants such as mercury, and/or sulphur and aromatic wastes from heavy oil processing, threat to human indigenous populations that lived there, as was demonstrated recently ${ }^{6-8}$ among others.

\author{
Machado Allison Antonio \\ Central University of Venezuela,Venezuela
}

Correspondence: Machado Allison Antonio, Academia de Ciencias Físicas, Matemáticas y Naturales; Instituto de Zoologíay Ecología Tropical, Central University of Venezuela Email Antonio.machado@ciens.ucv.ve; machado.allison@gmail. com

Received: December 22, 2016 | Published: January 03, 2017

As scientist that have the purpose to achieve an reasonable equilibrium among industrialization, conservation, and sustainable development, it is necessary to increase the knowledge, as how these aquatic ecosystems behave from the abiotic and biotic perspective, their importance in biological terms, production and use by human indigenous settlements, and how what protocols are needed to guaranty a adequate management of the whole system. It is naive to believe that the development of our countries could be achieve without causing some damage and losses of flora and wild life fauna. What we need is to guaranty or to prevent unnecessary damages applying modern techniques in some industrial exploitation, diminishing toxic wastes into the waters, and allowed future recuperation of the affected areas.

\section{Acknowledgments}

None.

\section{Conflicts of interest}

None.

\section{References}

1. Pringle CM, Scatema FN, Hansen PP, Nuñez-Ferrera M. River conservation in Latin America and the Caribbean (41-78). In: Boon PJ, Davies BR \& Petts G (Eds.), Global Perspectives on River Conservation: Science, Policy and Practice. John Wiley and Sons Ltd, UK. 2000.

2. Dinerstein E, Olson DM, Graham DJ, et al. A Conservation Assessment of the Terrestrial Ecoregions of Latin America and the Caribbean. The World Bank USA. 1995.

3. Olson DM, Dinerstein E, Canevari P, et al. Freshwater Biodiversity of Latin America and the Caribbean. A Conservation Assessment. America Verde Publ, Biodiversity Support Program, USA. 1998.

4. Chernoff BA, Machado-Allison K, Riseng J, et al., A Biological Assessment of the Aquatic ecosystems of the Caura River Basin, Bolivar State, Venezuela. Rap Bulletin of Biological Assessment 28. Conservation International, USA. 2003. 
5. Machado Allison A. Factors affecting fish communities in the flooded plains of Venezuela. Acta Biol Venez. 1994;15(2):59-75.

6. Machado-Allison A. La Minería en Guayana, sus efectos ambientales y sobre la salud humana. Bol Acad Ciens Fis Mat y Nat. 2015;LXXV(1):930 .
7. Red ARA. La contaminación por mercurio en la Guayana Venezolana: Una propuesta de Diálogo para la acción.Red Ara y Avina. 2013;pp.38.

8. Rojas M. Exposición ambiental y humana al mercurio en Venezuela: 2004-2008. Salus. 2010;14(2):33-40. 